Intersections

Canadian Journal of Music

Revue canadienne de musique
Intersections CANADAN TOURAA OP NUSIC

\title{
Lloyd Whitesell. 2008. The Music of Joni Mitchell. New York: Oxford University Press. 276 pp. ISBN 978-0-10-530799-3
}

\section{Olivia Carter Mather}

Volume 29, numéro 1, 2009

URI : https://id.erudit.org/iderudit/039120ar

DOI : https://doi.org/10.7202/039120ar

Aller au sommaire du numéro

\section{Éditeur(s)}

Canadian University Music Society / Société de musique des universités canadiennes

ISSN

1911-0146 (imprimé)

1918-512X (numérique)

Découvrir la revue

Citer ce compte rendu

Carter Mather, O. (2009). Compte rendu de [Lloyd Whitesell. 2008. The Music of Joni Mitchell. New York: Oxford University Press. 276 pp. ISBN

978-0-10-530799-3]. Intersections, 29(1), 135-138.

https://doi.org/10.7202/039120ar

Tous droits réservés (C) Canadian University Music Society / Société de musique des universités canadiennes, 2009
Ce document est protégé par la loi sur le droit d'auteur. L'utilisation des services d’Érudit (y compris la reproduction) est assujettie à sa politique d'utilisation que vous pouvez consulter en ligne.

https://apropos.erudit.org/fr/usagers/politique-dutilisation/ 
and it would strengthen her argument to dispute the issue at greater length in the body of her text. Given the significance of her findings, however, all this can be overlooked in favour of speedier dissemination of her research to a wide readership. In the fledgling field of early modern chant studies, every new study is eagerly awaited and indeed needed to spark ideas and suggest new directions for scholarship.

Kim identifies Merbecke in her book title as "orator." A Renaissance term used before humanista became current, orator implied a man of wisdom in whom the arts of rhetoric achieved their highest and deepest expression. Merbecke self-identified as an orator in the prefaces to his books and, according to Kim, he merits the designation, given the skill with which he transformed a Catholic, Sarum plainchant tradition into a Protestant, humanist expression of faith. Her arguments are convincing and, indeed, invaluable to studies of English music, Reformation history, and early modern plainchant reform. It is indeed the case, as Robin Leaver himself states in the foreword, that "this is an important book that deserves to be widely read and studied" (xviii).

BARBARA SWANSON

Lloyd Whitesell. 2008. The Music of Joni Mitchell. New York: Oxford University Press. 276 pp. ISBN 978-0-10-530799-3.

In the field of popular music, recent books on Led Zeppelin, the Beatles, Metallica, and Madonna have begun to construct a framework for the scholarly study of individual artists and bands. Lloyd Whitesell's The Music of Joni Mitchell joins this growing group of monographs that closely analyze limited repertoires to explore the function of the artist and to understand how individual songs create musical meaning. Aside from serving as excellent case studies of larger issues, by implication such projects claim that the output of the musician(s) in question is worth studying in itself.

In the case of Madonna, for example, it has been argued that she uses her position to mount a cultural critique of gender, at the same time maintaining power over her music, her image, and her career. However, much of what scholars find remarkable about Madonna appears earlier in the career of Joni Mitchell. Though Whitesell does not intend for his project to be a feminist one (and he quotes Mitchell's own objections to the label), his book nonetheless champions the work of an artist with exceptional control over her career and her music. Like other singer-songwriters, Mitchell sang songs she penned, accompanying herself. But in times when few artists-male or female-produced and arranged their recordings or painted their own album cover art, Mitchell enjoyed a great deal of creative authority.

From the outset, Whitesell states that his work is not about the larger "significance" of Mitchell in popular music or her relationship to culture. Instead, he looks at Mitchell as a songwriter and analyzes her songs in terms of 
"craftsmanship." Whitesell's study is a treatment of a composer's music, using a "fine art" model as his framework. Conscious of the evaluative baggage that often comes with such an approach, he explains that he does not invoke high culture to win prestige for Mitchell's music but to draw attention to the correlation between her works and art song. Most of Whitesell's interpretation relies on traditional musicological analysis. As a comment on debates over the value of analysis for popular music, he contends that "analytical techniques borrowed from art music can be useful as long as they remain flexible and sensitive to different generic conventions." Whitesell's undertaking is indeed an enlightening example of analysis tailored to its repertoire and "hybrid analytical practices, developed on an ad hoc basis" (11). His is also among the most beautifully written analyses in the field.

The chapters of the book follow a thematic course rather than a chronological one. After establishing his approach and reviewing Mitchell's stylistic periods (chapters 1 and 2), Whitesell turns to analysis, beginning with lyrics (chapters 3 and 4). Chapter 3 organizes her writing in terms of poetic categories (e.g., mode, representation, syntax, diction), and therefore delves much deeper into lyrical analysis than most studies of popular music by musicologists. Whitesell outlines the variety of rhetorical strategies at Mitchell's disposal that create her characteristic "vivid fictional characters and implied speaking presences" (42). In the next chapter, he pulls away from close investigation of words in an attempt to characterize all of Mitchell's work according to one central idea: personal freedom. Mitchell's explorations have produced several permutations of the theme of freedom, such as traps ("I Had a King"), quests ("Barangrill"), bohemia ("The Boho Dance," "Strange Boy"), talent and artistry ("For Free"), and flight ("Song to a Seagull" and the album Hejira). Chapter 4 is particularly impressive in its interpretations of lyrics in light of music; though this section is ostensibly devoted to poetic themes, Whitesell reveals the musical choices Mitchell has made to communicate larger ideas.

Chapters 5 and 6 contain the main musical analysis of the book, and it is through these two chapters that Whitesell articulates what makes Mitchell's music effective and unique. Impressive in their scope and detail, these chapters (on harmony and melody, respectively) model how careful and thorough analysis can illuminate popular music. As Whitesell does throughout the book, here he draws his arguments from the songs themselves; with copious examples, transcribed by the author and reproduced as piano reductions, Whitesell easily convinces the reader of his assertions. Through the discussion of harmony ("Harmonic Palette" as Whitesell calls it, appropriate for a musician who is also a painter), we learn that it is Mitchell's use of modes that gives much of her music its distinctive sound. Her use of harmony may be divided into five categories: modal (Mixolydian being one of the songwriter's favourites), polymodality (the most common format in Mitchell's work), chromaticism, polytonality, and pedal points. In some styles of popular music, traditional harmonic analysis is limited in its ability to reveal what a song is "about," especially if a songwriter relies upon existing harmonic conventions and forms. But in this case, intimate knowledge of Mitchell's harmony (her musical "box of 
paints") is necessary to understanding how Mitchell's songs can communicate freedom, entrapment, critique, and longing.

Incisive examination continues into chapter 6, which is devoted to melody. Again Whitesell inspects Mitchell's musical "toolkit," this time describing how she balances expansion and experimentation with formal organization. Mitchell's melodies are distinguished by "flexible phrase rhythm" (163) and "differing degrees of conclusiveness" at the ends of phrases (164). Chapter 7 illustrates how three of Mitchell's albums (Song to a Seagull, Hejira, and Don Juan's Reckless Daughter) behave like song cycles. To varying degrees, these albums project a sense of unity within themselves in lyrics ("central themes, recurrent motifs, unifying expressive tones, or overarching plans") and music ("motivic relations, continuity between adjacent songs, and overarching plans" [196]). This chapter contains some of Whitesell's most sensitive commentary, including a particularly loving discussion of Hejira.

The book probes deeply into dozens of songs, therefore making its scope narrow by necessity. Whitesell marks the boundaries of his study at the beginning of the text, stating that he "will not be judging the value of her music based on its influence, popularity, or exemplary nature as a chronicle of its times, though these are all topics worthy of consideration in their own right" (3). While the author has intentionally limited his study to analysis, historical background (in terms of musical style) would help to give a better sense of which musical gestures are remarkable and what they mean. Is her work part of a larger musical conversation? When is Mitchell building upon preexisting practices or when is she critiquing them? As previously quoted, the author seeks to be "sensitive to different generic conventions." The further scholarship on Mitchell that Whitesell calls for could investigate Mitchell's grounding in these generic conventions. For instance, is her use of modality an outgrowth of her interest in jazz, Western art music, folk music, or all three? As a resident of Los Angeles in the late 1960s and early 1970s, she likely drew from the work of her singer-songwriter peers. Similarly, her experiences as a Canadian living in the United States seem to have played a role in her writing.

Given that the object of investigation is the recordings, not their cultural significance, Mitchell's voice and instrumentation choices (aside from melody, harmony, form, and lyrics, those parameters that are easily conveyed by traditional notation) might augment interpretations of Mitchell's music. Short remarks on Mitchell's singing are peppered throughout the study, but her voice is not presented as the locus of expression that it is to many listeners. Much of the meaning in her songs comes from her performances of them and from her abilities as a singer. Attention to guitar arrangements (alternate tunings, picking style, voicing, etc.) are also an important part of what makes Mitchell's recordings hers.

Lloyd Whitesell's application of traditional analysis to popular music in The Music of Joni Mitchell is eye-opening in its description of Mitchell's creativity with harmony, melody, and poetry. His rich and nuanced account is an example of how to spotlight a single musician's work while avoiding pitfalls of 
hagiography. It is a significant addition to the emergent bibliography on individual artists and pop music studies broadly, as it sets new standards for close investigation of the musical elements of popular music.

Olivia Carter Mather 